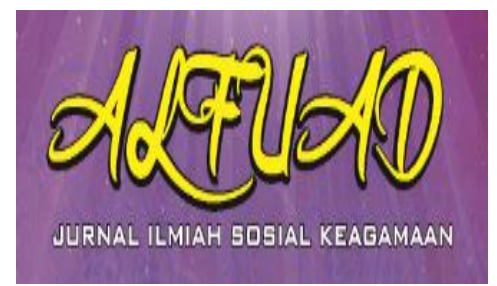

ALFUAD JOURNAL, 5 (1), 2021,(59-72)

(E-ISSN 2714-7606 P-ISSN 2614-4786 )

Available online at

http://ecampus.iainbatusangkar.ac.id/ojs/index.php/alfuad

\title{
Dakwah in The Study of Religious Moderation
}

\section{Uswatun Hasanah}

Institut Agama Islam Negeri Madura, Indonesia

E-mail: us hasanah29@yahoo.com

\begin{abstract}
Given that Indonesia is a pluralistic country consisting of various races, ethnicities, religions and languages. So the theme of religious moderation is considered important to be discussed and researched by academics in particular. However, this paper wants to see how the Prophet actualized the context of religious moderation in his preaching both in Mecca and preaching in Medina. The results of this study indicate that the Prophet succeeded in practicing the concept of religious moderation both during his time in Mecca and while in Medina, he managed to coexist with people from various ethnic backgrounds, tastes, religions and cultures in peace, harmony, and prosperity, especially during his time in Medina. Not only that, he also succeeded in making Islam the majority religion in Arab land at that time. This research is a qualitative research, the type of literature review data is obtained through books and articles or journals that are relevant to this research. The data that has been collected are described in detail and structured.
\end{abstract}

Keywords: Moderation, Dakwah, History

\section{INTRODUCTION}

The theme of religious moderation is actually not new in Islam. Although in terms this theme can be said to be new, in practice Muhammad as a chosen person has practiced the concept of religious moderation both when he was still in Mecca and after moving to Medina. In Indonesia itself, many terms are used to describe the concept of religious moderation such as Nusantara Islam, moderate Islam, wasathiyah Islam and so on. But in essence, what Islam means is Islam rahmatan lil alamain, namely how Islam can be a mercy for the universe. This is important to be socialized considering that Indonesia is a diverse country consisting of various ethnicities, races, religions, cultures, social, languages and so on.

In a multicultural society, diversity and culture become the most valuable social capital in order to create social harmonization. Therefore, in multiculturalism, everyone has the right to be treated equally before the law (Setiawati, 2012). In multicultural life, understanding and awareness of multiculturalism is needed which is shown by mutual respect for differences, pluralism and the ability to interact with anyone fairly. The attitude of religious moderation can be in the form of acknowledging the existence of other parties, having a tolerant attitude, respect 
for differences and not forcing the will on other parties (Akhmadi, 2019).

The term of religious harmony is synonymous with the term tolerance. The term tolerance refers to the meaning of mutual comprehending and understanding then opening up to each other in the frame of brotherhood. Islam teaches to live in peace, harmony and tolerance. While religious harmony is a condition in which inter-religious people can accept each other, respect each other's beliefs, help each other, and work together in achieving common goals (Rusydi, 2017).

In Shihab's view, it is important to increase knowledge about Islam and Islamic culture, also national culture that does not conflict with Islamic teachings. So that we have the ability to connect the bright past and the present that is filled with uncertainty as well as this becomes a path that leads to a brighter future (Shihab, 2019: 10-11). The Qur'an records all aspects of life because its function is not only the holy book of Muslims, but it functions as a source of law, guidance, source of historical, advice and so on. In addition to the Qur'an, Islam has hadith that can be used as other sources of knowledge. Adequate knowledge is expected to be able to minimize conflicts both among Muslims themselves and between Muslims and non-Muslims.

The attitude of exclusivity among certain circles is motivated by the assumption that he is the most correct and blames others. This kind of attitude was never exemplified by the Prophet even though at this time he was a prophet and messenger whom Allah ordered to straighten the faith and improve human morals at that time. Because, as stated by Shihab that the pinnacle of the Islamic faith is awareness and acknowledgment of the existence of God Almighty, in this case the position of Islam is between those who deny the existence of God and those who believe in many Gods. In addition to using the spiritual potential of Islam, it also invites its adherents to maximize their minds in honing their belief in God, so that when the eyes are unable to read the sheets of the universe, the eyes of the heart will find and feel His form (Shihab, 2019: 46).

However, there is no compulsion in Islam to embrace Islam as a religion and accept Allah and His Messenger as the Essence of the faith, one's religion is completely the right of everyone. Because with him Allah has given reason as a tool to seek the truth. In the context of Islam, Allah does not treat humans like the universe that has no choice, nor does it like animals that do not have reason to choose, humans as chosen and special creatures are equipped with reason to choose and seek the truth about their God. (Surat al-Maidah [5]: 48). If God wants all mankind to worship him, then God will not provide humans with will and various kinds of potential, besides that God also gives instructions on how to manage reason, potential and instructions that have been given (Shihab, 2019: 45).

In his preaching, the Prophet prioritized morals rather than violence, at the beginning of his preaching the Prophet only conveyed to those closest to him in a secret way, before conveying his da'wah openly received strong rejection from the Jews even by his own uncle Abu Lahab, not only hindered his preaching and even Abu Lahab's crime against his nephew, by placing coals of fire and himself along the path that the Prophet used to go through until this incident was enshrined in the Qur'an (Surah al-Lahab [111]: 1-5). However, the Prophet did not put up a 
brutal fight against his uncle's attitude. $\mathrm{He}$ can still live in the harmony with them and other Jews.

Based on the above background, the researcher is interested in researching the da'wah of the Prophet in the concept of religious moderation which has been practiced by the Prophet both during his time in Mecca and Medina.

In introduction, authors should state the objectives of the work at the end of introduction section. Before the objective, authors should provide an adequate background, and very short literature survey in order to record the existing solutions/method, to show which is the best of previous researches, to show the main limitation of the previous researches, to show what do you hope to achieve (to solve the limitation), and to show the scientific merit or novelties of the paper. Avoid a detailed literature survey or a summary of the results.

\section{METHOD}

The methodology in this research is qualitative with a descriptive approach, this research is a type of literature review research. Sources of data in this study are reference books on the history of the Prophet, journals and articles related to the history of the Prophet and Islamic civilization before and after Islam came to Arabia. The data that was collected was then described in detail and structured in this study.

\section{RESULT AND DISCUSSION}

Religious moderation or wasathiyyah taken from the word wasatha has many meanings. It is something that is at both ends at once, it is part of it, it can also be interpreted as the middle of everything, it can also be interpreted fairly (Shihab, 2019: 486). Moderation is not an indecisive or unclear attitude towards something, nor is it a mathematical middleman, nor is it gentle, although one of the indicators of moderation is gentleness and courtesy, but that does not mean that it is not firm in all matters (Shihab, 2019: xi.a).

Wasathiyah or religious moderation is the middle way in religion, it does not lean towards one pole. The left pole or the right pole, neither extreme nor loose in terms of religion. Local wisdom is one of the mainstays in producing religious attitudes and moderation. Religious moderation is an effort to maintain harmony in the midst of existing differences (Arafah, 2020). Wasa'iyyah is attached to the group that leans towards Ahlus Sunnah wa al-jama'ah, (Asy'ariyah and Maturidiyah). Maqashid shari'ah arises as a result of debate among fiqh experts regarding shari'ah, which has a certain 'illat (causa) or not (Azhari, 2020). Moderation of Islam is reflected in an attitude that is not easy to blame, let alone to disbelieve in people or groups with different views. Islamic moderation prioritizes brotherhood based on the principle of humanity, not only on the principle of faith or nationality. Such an understanding found its momentum in the Islamic world in general. (Darlis, 2017).

Moderation is concluded by Shihab as a balance in all matters of worldly life and hereafter, which must always be accompanied by efforts to adapt to the situation at hand based on religious instructions and the objective conditions being experienced (Shihab, 2019: 43). Based on (QS. al-Baqoroh. [2]; 143) religious moderation is based on: tawasuth (taking the middle way), tasamuh (tolerance), tawazun (continuous) i'itidal (straight and firm), ibtikar and tathawwur 
(innovative and dynamic), musawa (egalitarian), shura (choosing priority).

Religious moderation is the main characteristic of Islamic teachings, it is not a new sect or teaching, so it is not surprising that it is not attributed to one group by ignoring other groups. Religious moderation also cannot be claimed as belonging to certain groups (Shihab, 2019: 38). The arrival of Islam shows that religion was born at a time of tension between two opposing world ideologies. Eastern (Persian) ideology which tends to spirituality and Western (Roman) ideology which tends to material. Islam came between the above contradictions, by taking the middle way which then led to the glory of the world (Suharto, 2019: 68).

In the Indonesian context, religious moderation is an effort to maintain tradition and sow friendly Islamic ideas. In addition, religious moderation is an option to maintain Indonesia's diversity without having to revoke existing cultural traditions (Suharto, 2019: 46).

Islamic Da'wah In terms of language and definition, da'wah has equivalent words with the terms tablig, sermon, nasihah, tabsyir wa tandzir, washiyyah, amar ma'ruf nahi mungkar, and tarbiyah wa ta'lim, each of which comes from Arabic but in translation often times an error occurs (Aziz, 2017: 17). Da'wah is an effort to convey something to others, either to individuals or groups about the views and goals of human life according to Islam. Da'wah aims to convey the truth that is in the Qur'an and hadith and invites people to practice it (Syamsuddin, 2016: 10-11).

Moderation of da'wah is calling for doing good and charitable ma'ruf nahi mungkar, trying to be in a middle position, neither extreme nor too loose. Moderation of da'wah in social media must reflect as an area of contestation to win the hearts of the people in order to build a new civilization in the world of da'wah, among the approaches that can be taken are; First, package the message of da'wah in the digital era. Next, digitizing da'wah through the website. Three, maximizing da'wah videos in the digital era. And the last thing is the moderation of da'wah in the form of articles, and Fifth, moderation of da'wah in the family (Sutrisno, 2020).

In terms of the essence of da'wah, it is not only limited to explaining and conveying, but also touching on coaching and takwin (formation) of personal, family and community (Pirol, 2018: 8-11). Da'wah is a necessity for Muslims, because Islam itself introduces itself as a religion of da'wah. This means that the presence of Islam on this earth cannot be separated from da'wah activities, the existence of da'wah both as an idea and a process, cannot be separated from the instructions of the Qur'an (Wahid, 2019: 11-14). Every Muslim can preach based on the abilities and capacities he has, a teacher can preach with his profession as an educator, both da'wah bil oral and da'wah bil hal. Da'wah is not always carried out on the pulpit by a da'i, a teacher can preach through the profession he has, he can set a good example, both for his friends who are in the same profession and his students, as well as other professions. other. They can preach with the abilities and media they have.

Islamic da'wah is not propaganda both in terms of intentions and in terms of goals. The intention of da'wah is sincere because of Allah and free from subjectivity, da'wah also does not justify any means to achieve its goals. Da'wah must be open, free and honest, the 
orientation of da'wah is the formation of a fitri and azali life attitude (Ismail, 2011: 11-14). We can pay attention and see how the da'wah of the Messenger of Allah even with a fairly heavy challenge, he never returned badness for evil, it was appropriate when he became a role model for his people. In preaching he prefers benefit, when he feels unable to protect religion and his followers he prefers to move/hijrah, a wise action that can be imitated in everyday life.

The strategy of the Prophet's da'wah during Medina included: Building a mosque as a medium and center for da'wah. Al-Mu'akhat or creating brotherly relations between Muhajirin and Ansor. Treaty with the Jews of Medina. Establishment of the Medina Charter as a conflict resolution. One of the challenges of da'wah is the refusal of the Medina Jews who are so hard, but Prophet Muhammad was able to face the challenge. This is proven today, the entire population of Medina is Muslim (Anas, 2017).

Tolerance is not a theological acknowledgment of the truth of other religions, every religion only believes in the religion it adheres to as the truest religion to get true happiness, namely the happiness of the world and the hereafter, tolerance is more about acknowledging the existence of each religion with all its characteristics and diversity so that it will growing mutual respect and respect between religious adherents (Wijaya, 2020:336). Although the practice of religious tolerance of the Prophet while in Mecca was not as conspicuous as in Medina, based on several references it was described that he was more silent than fighting because one of the important tasks he carried out as a prophet was perfecting morality. So, he chose to be passive to guard against the aggression of the people of Mecca at that time.

The next section will classify the da'wah of the Prophet, the first is the period of da'wah in Mecca and the second is the period of da'wah in Medina. Both have different da'wah characteristics. Da'wah in Mecca was more about cultivating faith, the Mecca period was the first da'wah where the people faced had a strong enough character to hold the beliefs of their ancestors, da'wah in Mecca the Prophet experienced many rejections to the point of death threats and anarchic behavior, while in Medina he no longer focuses on cultivating faith because some of the people of Medina have brought Islam after their pilgrimage to Mecca.

The people of Medina welcomed the arrival of the Prophet, even though at that time Medina was also a plural society. However, in Medina the Messenger of Allah was not only a messenger or a religious leader but he was also a head of state who protected the population with the diversity that existed. 10 years in Medina was able to bring Islam to all corners of the world through companions sent by the Messenger of Allah who later would also be continued by the Prophet Muhammad and his companions: Abu Bakr, Umar bin Thattab, Uthman bin Affan and Ali bin Abi Talib.

\section{The Genealogy and Life of the Prophet Before His Appointment}

The Arabs made a significant contribution to the modernization process of the Western world. Arabs as heirs of ancient civilizations succeeded in absorbing and integrating various elements of Greco-Roman culture so that Arabs succeeded in becoming the pioneers of the birth of an intellectual movement to 
Europe in the Middle Ages (Hitte, 2002: 4). This is inseparable from the role of the Prophet as the chosen human being who was sent to deliver the message of Islam to all corners of the world, after he died the struggle for the spread of Islam was continued by his companions or what we know as Khulafatur Rashidun, the Caliphate period ended during the time of Hasan bin Ali as a substitute for his father, in a short time the leadership was handed over to Muawiya bin Abi Sofyah who was also the leader of the Umayyads, Islam reached the peak of glory and the golden age during the caliphate Harun Ar-Rasyih of the Bani Muawiyah. In this section, we will describe a little lineage and the person who brought truth and knowledge to the universe

The Messenger of Allah was bom from a high lineage, namely the Hasyim children who are still connected to Ismail, the Hasyim children are attributed to his grandfather, Hasyim bin Abdul Manaf, Hasyim is the person who is responsible for handling water and food affairs for those who perform the pilgrimage. $\mathrm{He}$ is an honorable rich man, he is also the one who opens trade routes twice a year (Rahayu, 2020: 1). While his greatgrandfather Qusai ibn Kalab was the founder of the Quraysh tribe, he managed to unite a clan that was previously divided due to feuds and had a loose system of ties of lineage and marriage, Qusai managed to form a new tribe that was exactly the same as when Mecca became a popular center for the long-distance trading (Armstrong, 2006: 2).

Muhammad's full name is Muhammad bin Abdullah bin Abdul Muttalib bin Hasyim bin Abdi Manaf bin Qushay bin Kilab bin Murrah bin Ka'ab bin Lu'ay bin Ghalib bin Fihr bin Malik bin Nadhr bin Kinanah bin Khuzaimah bin Mudrikah bin Ilyas bin Mudhar bin Nizar bin Ma 'ad bin Adnan. Adnan's lineage ended in Sayyiidina Ismail bin Ibrahim (Fathurrahman, 2017: 3). Prophet Muhammad was the only person born to two parents who wanted to be sacrificed, first was Ismail who his father wanted to sacrifice because of Allah's command, the second was Abdullah the prophet Muhammad's father who wanted to be sacrificed because his grandfather Abdul Muttalib's vow was related to what his vows if he is blessed with 10 sons then he will sacrifice one of them and after going through the lottery then his father's name comes out after three consecutive draws.

Before he was born, his father died when he was 7 months old in his mother's womb, little Muhammad was raised by his uncle and grandfather, as is the custom of the people of Mecca, every baby born is entrusted to the Bedouin community to be breastfed for two years, as well as the prophet Muhammad he was raised by Halimatus Sa'diyah and her husband. Muhammad became a blessing in itself to their family, their family who was originally a poor family became rich in their village because their livestock and business were successful. So it's no wonder when it was time for Muhammad to return to Mecca Halimatus and her husband asked permission to take care of Muhammad a little longer and Aminah allowed to take care of Muhammad even longer.

Muhammad grew into a young man who was directly in the care and protection of Allah SWT, Allah guarded him from ignorance in the midst of his people. Muhammad became a teenager whose main personality was the best in character, the noblest in lineage, the best in neighbors, the highest in politeness, the furthest from abominations, the most honest and most truthful in speech (Hasyim, 2019: 81). So it is not surprising 
that when he got the nickname al-amin from his people, before being appointed as the prophet Muhammad, he had been preserved from immorality and mistakes. One day he invited friends his age to attend a Mecca community celebration which included drinking, playing women and gambling. To cure curiosity with the tradition he promised to attend with his friends, apparently Allah did not allow Muhammad to be present at the celebration of the Jewish community at that time three nights in a row he always fell asleep.

At the age of children Muhammad had experienced an incident that made Halimatus Sa'diayah and her husband scared and worried, one day when Muhammad was playing with his friends Jibril came to cut his chest, spontaneously his friends reported this to Halimatus Sa'diyah, it turned out that after seeing there was no trace of forgetting anything in his stomach. Not long after that incident Muhammad was returned to Mecca to his family.

Another spectacular incident experienced by the prophet Muhammad was that at the age of 15 he had participated in the dawn war, namely the war that took place between Bani Quraysh, Bani Kinanah, Bani Qais Ailan. This war occurred because of violations of the sanctity of the forbidden land and the holy months (Ayyasi, 2009: 26). Apart from this incident, he also often accompanied his uncle Abdul Muttalib in trade to Sham, he was an intelligent and hardworking young man. At the age of twelve he asked his uncle for permission to trade independently. He can be said to be an accomplished businessman at a young age for a beginner. One indicator that describes that he was successful in business is his ability to give a dowry to Khadijah, whom he married at that time, namely 20 shecamels, besides that he was able to take care of Ali bin Abi Talib who was none other than his cousin, his uncle's son who had been taking care of him.

Muhammad married Khadijah at the age of 25 and Khadijah was then 40 . Khadijah comes from her own people, namely the Bani Quraysh whose full name is Khadijah bint Khuwailid, she is known as a wealthy widow who is respected because she has succeeded in being an example for her people because of her ability to organize she is nicknamed "aththahirah" (the holy) (Razwy, 2004: 29). Khadijah will be the one who will believe, support and motivate the Prophet in his da'wah. Especially in difficult times of the prophet's da'wah, not only moral support but also wealth. Her wealth was used up to defend Islam, that's why Khadijah has a special place in the heart of the Prophet because, when many people did not believe in Muhammad as the messenger of Allah, Khadijah who had a strong belief in that, in the womb of Khadijah was born Fatima, a beautiful and beautiful daughter. intelligent. Khadijah became the wife who was most loved by the Prophet even until Khadijah died.

\section{Description of the 13 years of the Prophet's Da'wah in Mecca}

Mecca was a tribal society until the end of its conquest at the time of the prophet Muhammad, the population system was built based on the tribes and the advantages possessed by a person were usually the pride of his tribe such as swordsman, brave, many descendants, or other advantages (Al-A'zami, 2005). : 20). From an economic point of view, Mecca can be said to be a rich city, they are experts in commerce, not only doing 
business within the city of Mecca but also they are trading outside the city like Sham.

The religious style of the Meccan people before the arrival of Islam was the Hanafis, namely groups who were looking for the Abrahamic religion which was still pure and not contaminated with lust by worshiping idols (Wendi, 2020: 11). However, the religion brought by the prophet Abraham was lost from the people of Mecca at that time, they worshiped idols as intermediaries for worshiping Allah. The religions adopted at that time were Judaism and Christianity, one of the positive sides of the people of Mecca was that they were compact in working together, having an extensive network, especially in the trade sector.

The condition of Mecca before the Prophet was appointed as a prophet and messenger from a socio-cultural perspective, including people who were far from human values, they had the habit of gambling, drinking liquor, molesting, eating carrion, discrimination against women and other atrocities. Before being appointed as a messenger, Muhammad saw and paid attention to how they worshiped. However, the prophet Muhammad did not get involved in the habits of ignorance. This is what later became one of the reasons he often persisted in the cave of Hira. One place away from the hustle and bustle of the city of Mecca at that time.

It was in that place that the prophet Muhammad pondered about the actions of the people of Mecca, until the angel Gabriel came to meet him to deliver revelations. This incident became the origin of the prophet Muhammad knowing the truth until he was appointed as the messenger in charge of conveying the truth. Re-aligning the teachings of the prophet Ibrahim who had been lost in the city of Mecca at that time. The task of da'wah has been carried out by him, so the first people who were invited to embrace Islam were those closest to him such as his family Khadijah, Ali bin Abi Talib, his cousin, Abu Bakr, his companion, his adopted son who was freed from the slavery of Zaid bin Harithah, Umm Aiman and Bilal bin Abi Rabah. In the early days of his da'wah, the Messenger of Allah conveyed in a secret way. One of the reasons at that time was the strong belief of the people of Mecca in the religion of their ancestors, some of which said it was due to economic factors because the largest supply at that time was from the sale of the statues they worshiped.

At the stage of open preaching the prophet Muhammad met and mingled in the midst of the community to deliver new messages, preach and teach, however, they laughed and insulted him. At this stage the Messenger of Allah carried out his role as a warning nadzir (Surah [67]: 26 and [51]: 50-51) as well as being a prophet who continued to carry out his mission (Hitti, 2005: 142). Although in his preaching he often met resistance, even to the point of threatening to kill the prophet Muhammad, he almost never fought back. One day he was doing tawaf when suddenly he was beaten until he bled. Aisha who saw the incident went to Abu Bakr to ask for help, and Abu Bakr rushed to help and protect the Messenger of Allah. However, the Jews continued to torture him until both of them passed out unconscious.

The second incident was when the Messenger of Allah had just experienced the isra 'mi'raj incident without suspicion and with full confidence the incident was told to Abu Jahal who incidentally was a person who was hostile to Islam. Abu Jahal used this opportunity to berate and insult 
the Prophet because what happened to the Prophet did not make sense, at that time people who had believed in the Prophet had apostatized because they were provoked by Abu Jahal's words and at that time he did not fight back. His important mission as a human messenger was to improve morals and to imitate the people of Mecca with his gentle preaching, without compulsion and violence.

The atrocities of the Jews were often accepted by the Prophet Muhammad and his companions who embraced Islam, so as to protect them and protect the religion. Rasulullah then ordered them to move to Habasyah (Eutopia), they migrated there. Among the companions who joined the migration at that time were Uthman bin Affan, Ruqoyyah bin Muhammad, Abdurrahman bin Auf and others (Al-Buthy, 2009: 131). King Najashy received the companions very well, they were given protection and allowed to mingle with the local people, even though they were Christians. This is one proof that the prophet Muhammad had good relations with non-Muslims even though they were outside the city of Mecca.

One of the factors in the rejection of the Qur'an and the people of the book to accept the teachings of Muhammad SAW is the interest of religion, for them religion is a sensitive matter. Religion cannot be replaced by a new religion unless there is an awareness that the old religion no longer provides spiritual satisfaction. Religion for each individual as an urgent and private guide in life and living. For the infidels of Mecca, the arrival of a new teaching brought by Muhammad SAW was a threat to the existence of the religion he adhered to (Asmaya, 2014). Before Umar took the shahada, he was one of the
Quraysh who hated the prophet Muhammad so much that he even spread the news that he was going to kill the prophet Muhammad, but what happened when the Messenger of Allah met Umar? The Messenger of Allah only conveyed the truth and Umar immediately took the shahada at that time, after Umar understood and understood that what the Prophet was doing was the truth, he guarded the Messenger of Allah to fight against the Quraysh again he chose to be patient in the process of his da'wah. Various tortures, insults, insults and baseless accusations were often received by the Prophet during his preaching in Mecca.

Prophet Muhammad's life while in Mecca was more focused on inculcating the values of aqidah, rather than other aspects of life, in contrast to his condition in Medina, where many people had embraced Islam. And they were more accepting of the prophet Muhammad and the other companions, so that his da'wah was not only in the field of aqidah, but he began to organize the fields of economy, science, politics, military and so on. His presence in Medina was enough to inspire and motivate him to continue his da'wah. In the Meccan period, what was more striking was how his morals and behavior towards those who opposed his da'wah, as the researcher explained in the previous section.

\section{Portrait of the Prophet's 10 Years of Religious Moderation in Medina}

The first thing the Messenger of Allah did when he arrived in Medina was to build a mosque. The mosque which then functioned not only as a place of worship for Muslims, but also had many functions including a place of learning, a place of 
deliberation. From the mosque, ukhuwah Islamiyah among Muslims themselves is getting stronger. He realized that hijrah was not an easy decision that he took, because he had to leave their family and property what's more, this hijrah was carried out in secret to avoid prying eyes from the Jewish community, and was carried out in stages. The companions who migrated with the Prophet were divided into several groups to avoid the suspicion of the Quraysh for the development of science in the early days of the Prophet living in Medina, he once appointed a secretary with a Jewish religious background, because that person was considered to have Hebrew language skills, thus he could work with non-Muslims (Wijaya, 2020: 348).

It is undeniable that the people of Medina accepted the Prophet with joy, even his arrival was greeted with badr prayers. This is contrary to the acceptance of the people of Mecca at this time, the Messenger of Allah built Medina into a city full of peace and inter-religious harmony. Even though there was a war he was forced to do it because the people of Mecca were still not satisfied to torture the prophet Muhammad and his followers. It seems necessary to emphasize here that the prophet Muhammad and the Muslim troops were forced to take up their swords not because of the purpose of making accusations but rather for the protection of themselves, their religion, their property and their families as stated by Shihab that, the permission for war given by the Prophet in the case of Quraizah was not in the context of kufr or non-Islam but rather on interference with religion, it means that war is carried out with the aim of defending religious values (Shihab, 2019: $65)$.
The Medina Charter was born at the beginning of the prophet Muhammad's presence in Medina, he was made and agreed upon in peaceful situations and conditions, there was no intimidation, coercion, or pressure, agreed upon by people with various ethnicities, races and religions at that time, acknowledging the differences that existed in the world. between them and run according to their respective beliefs. In addition, there are no articles in the Medina Charter that are contrary to the principles of Islamic teachings (Shihab, 2018: 180. However, the Medina Charter is made in the social conditions of a plural society. Society is divided into different ethnic, racial and religious groups (Romdhoni, 2014: 14). The Medina Charter as a form of peace unites tribes that are still tribal who are often in conflict as with socio-cultural conditions at that time. Second, the conflict mapping of the Medina Charter cannot be separated from the conditions and positions of Muhammad Saw. Conflict mapping internally between tribes there which positioned Muhammad as a peacemaker. The main issues in the Medina Charter were safety, resource power, while the supporting issues in the Medina Charter included the unity of the people, law enforcement, Muslim unity, general protection, minority protection, and the highest power in law as stated in pa the articles of the Medina Charter (Burhanuddin, 2019: 1-20).

The diversity of the people of Medina does not make the Messenger of Allah discriminate against them, the Prophet upholds justice and respects each other. On one occasion the Prophet was asked to decide a law relating to theft, murder and adultery by the Jewish community. At that time, the Prophet had 
refused and handed over the problems to them and asked them to decide this case based on their religion, however, they refused and forced the Prophet to decide the law on the grounds that the Prophet was the most just person (Gulen, 2012: 137).

While Bai'at Aqobah is a political move of the Prophet Muhammad which is motivated by the meeting of two interests in one historical momentum, namely the interest to transmit Islamic teachings to the people of Yathrib and the interests of the Yathrib community for the presence of a leader who can gather them into a social order that orderly, peaceful and just. These two interests were realized through a written agreement (the Medina Charter) as a form of his political policy in the field of law. The Medina Charter is a crystallization and legalization of various Medina political interests which are actually plural in religion, ethnicity, and ethnicity to realize legal certainty and social order (Fajar, 2019).

The Medina Charter can be an example for all mankind, tolerance, respect, love without being hostile, hate and berate, to create a country full of peace, harmony among all its people. The Prophet succeeded in uniting diversity in the social life of the people of Medina at that time. He was also able to erase tribal primordialism among Muslims, both from the Aus, Khazraj and other tribes from the Muhajirin. Historical facts prove that brotherhood built on the basis of religion is able to defeat close blood brotherhood (Ali, 2017).

All the causalities in the Medina Charter governing Jews and Christians have united the people of Medina and kept them away from Byzaitum and Sasanid and Quraysh. At that time the Jews could live in Medina with a sense of peace and tranquility. The Medina Charter guarantees safety, peace and inter-religious harmony (Gulen, 2012: 145-146). The success of the Prophet in building the city of Medina into a peaceful, harmonious and prosperous city does not necessarily forget the other side of his life, it is recorded that while he was in Medina he fought wars of approximately 27 times, nine times he directly led the war, the rest he only sent friends to fight. down to the battlefield. However, the war waged by the Prophet against the Quraysh solely wanted to protect Muslims and the existence of the Islamic religion at this time. Even though Rasulullah had moved to Medina and built the city, Quraysh did not remain silent, Rasulullah was still considered a barrier, what more with the success of Rasulullah at that time in building Medina.

The Messenger of Allah together with his troops had indeed surrounded the Banu Quraizhah, after they repeatedly violated the agreement (the Medina charter) that had been agreed with the Muslims and repeatedly tried to kill the Prophet (Shihab, 2019: 87). The life of the Prophet while in Mecca, is enough to prove that he did not arbitrarily commit violence, even though what Quraish did was beyond common sense. The war carried out by the Prophet was not a form of forcing him to the Quraysh so that they embraced Islam. Because, basically Islam does not force its creatures to embrace one religion. The problem of religion is the full right of humans to choose the religion they believe in, because Allah has given reason and other potentials to find the truth.

Another historical trace that the Prophet was able to build religious moderation during his life is as quoted by Shihab, namely about the prophet 
Muhammad's agreement with the Najran Christians "I promise to protect them and defend them, their churches and places of worship as well as places where monks and priests live. -their priest. I also promise that I will protect their religion and their way of life wherever they are" (Shihab, 2019: 50). The Prophet Muhammad during his lifetime until he died managed to establish harmonious relations with the rulers and Christians this can be seen from: the moral support of the Muslims to the Romans (Byzaitum) the second was when the Muslims migrated to Habasyah (Ethiopia) King Habasyah allowed the Muslims to live in peace and embrace Islam in their territory, the third is during his lifetime the prophet Muhammad sent letters to the kings of the Christians, even though they refused the prophet Muhammad's invitation to embrace Islam they refused in a good way even the prophet was given two women Mariah and Syrin and clothes and a mule (Shihab, 2019: 2019-221).

\section{CONCLUSION}

The historical traces of the da'wah of the Prophet, both during his 13 years in Mecca and Medina for 10 years, were not only able to conquer them and make them the mecca of Islamic civilization, but also succeeded in changing their socio-cultural order. Islam under him did not only cover the issue of cultivating faith, in the next stage Islam succeeded in touching all aspects of life; military, political, cultural, educational and so on. Second, the plurality of Medina's motives, both in terms of race, culture, religion and sociality, is not a factor in the division of Muslims. The Prophet succeeded in building Medina with the diversity that existed, he was able to create a harmonious, peaceful and prosperous life. Conducive conditions become the spirit and motivation for Muslims, so that Islam can spread to all corners of the country.

\section{REFERENCES}

Akhmadi, A. (2019). Moderasi Beragama Dalam Keragaman Indonesia Religious Moderation in Indonesia's Diversity, Jurnal Diklat Keagamaan, 13(2), Pebruari - Maret.

Al-A'zami, M. M. (2005). Sejarah Teks alQur'an dari Wahyu sampai Komplikasi: Kajian Pembanding. Jakarta: Gema Insani Pres.

Ali, Ummu Salamah. (2017). Peradaban Islam Madinah (Refleksi terhadap Primordialisme Suku Auz dan Khazraj), Kalimah: Jurnal Studi Agama-Agama dan Pemikiran Islam, 15(2), September.

Anas, A., \& Adinugraha, H. H. (2017). Dakwah Nabi Muhammad terhadap Masyarakat Madinah Perspektif Komunikasi Antarbudaya, Ilmu Dakwah: Academic Journal for Homiletic Studies 11(1).

Arafah, S. (2020). Moderasi Beragama: Pengarusutamaan Kearifan Lokal Dalam Meneguhkan Kepelbagaian (Sebuah Praktik pada Masyarakat Plural), MIMIKRI, 6(1). Juni.

Armastrong, K. (2006). Muhammad: Prophet for Our Time, Terj. Yuliani Lipoto. Bandung: Mizan Pustaka.

Asmaya, E. (2014). Implementasi Metode Dakwah Islam Ala Nabi Muhammad Saw di Indonesia, Komunika, 8(2), Juli Desember. 
Ayyasi, M. A. (2009). Strategi Perang Rosulullah. Jakarta: Qultum Media.

Azhari, M. Luthfi. (2020). Moderasi Islam dalam Dimensi Berbangsa, Bernegara Dan Beragama Perspektif Maqashid AsySyari'ah, Jurnal Intelektual: Jurnal Pendidikan dan Studi Keislaman, 10(1), April.

Aziz, Moh. A. (2017). Ilmu Dakwah: Edisi Revisi. Jakarta: Kencana.

Burhanuddin, M. (2019). Conflict Mapping Piagam Madinah (Analisa Latar Belakang Sosiokultural Piagam Madinah), Jurnal AlIjtimaiyyah: Media Kajian Pengembangan Masyarakat Islam, 5(2) Juli-Desember, 1-20.

Darlis. (2017). Mengusung Moderasi Islam Di Tengah Masyarakat Multikultural, Rausyan Fikr, 13(2). Desember.

Fajar. (2019). Praksis Politik Nabi Muhammad SAW (Sebuah Tinjaun Teori Politik Modern dan Ketatanegaraan), Jurnal Hukum dan Politik Islam, 4(1), Januari.

Fathurrahman, M. (2017). History of Islamic Civilization: Peristiwaperistiwa Sejarah Peradaban Islam. Yogyakarta: Garudhawaca.

Gulen, M. F. (2012). Cahaya Abadi Muhammad SWA Kebanggaan Umat Manusia. Jakarta: Republika.

Hasyim, Ibnu. (2019). Sirah Nabawiyah: Sejarah Kehidupan Nabi Muhammad Terlengkap Dan Terautentik. Jakarta: Qisthi Press.

Hitti, P. K. (2005). History of the Arab: Rujukan Induk Paling Otoritatif Sejarah Peradaban Islam. terj.
Cecep Lukman Yasi dan Dedy Slamet Ready. Jakarta: Serambi.

Ismail, I., \& Hotman, P. (2011). Filsafat Dakwah: Rekayasa Membangun Agama dan Peradaban Islam. Jakarta: Kencana Prenamedia Group.

Pirol, A. (2018). Komunikasi dan Dakwah Islam. Yogyakarta: Deepublish.

Rahayu, S. J. (2020). Cinta Rosul: Meneladani Rosulullah melalui Sejarah. Terj. Dede Azwar. Jakarta: Qibla.

Razwy, S. A. A. (2004). Muhammad SAW: Sejarah Lengkap Kehidupan dan Perjuangan Nabi Islam Menurut Sejarah Timur dan Barat. Jakarta: Pustaka Zahroh.

Romadhan, Said Al-Buthy. (2009). Fiqih Siroh: Hikmah Tersirat Dalam Lintas Sejarah Hidup Rosulullah. terj. Fuad Syaifudin. Jakarta: Mizan Publikasi.

Romdhoni, A. (2014). Piagam Madinah: Bukan Konstitusi Negara Islam. Depok: Literatur Nasional.

Rusydi, Ibnu. (2018). Makna Kerukunan Antar Umat Beragama Dalam Konteks Keislaman Dan Keindonesian, al-Afkar, Journal for Islamic Studies, 1(1) January.

Setiawati, Nur. (2012). Tantangan Dakwah Dalam Perspektif Kerukunan Antar Umat Beragama, Jurnal Dakwah Tabligh, 13(2), Desember.

Shihab, M. Quraish. (2019). Al-Maidah 51: Satu Firman Berbagai Penafsiran. Tangerang: Lentera Ilmu.

(2018). Islam yang Saya Pahami: Keragaman itu Rahmat. Tangerang: Lentera Hati.

(2019). Islam yang Disalahpahami: Menepis Prasangka, Mengikis 
Kekeliruan. Tangerang: Lentera Hati.

- (2019). Islam yang Saya Anut: Dasar-dasar Ajaran Islam. Tangerang: Lentera Ilmu.

- (2019). Wasathiyyah: Wawasan Islam tentang Moderasi Beragama. Tangerang: Lentera Ilmu.

- (2020). Kosa Kata Keagamaan. Tangerang: Lentera Ilmu.

Suharto, B. (2019). Moderasi Beragama: Dari Indonesia untuk Negara. Yogyakarta: LKis.

Syamsuddin. (2016). Pengantar Sosiologi Dakwah. Jakarta: Karisma Putra Utama.

Wahid, A. (2019). Gagasan Dakwah: Pendekatan Komunikasi Antar Budaya. Jakarta: Kencana.

Wendi. (2020). Sejarah Peradaban Islam. Boyolali: Lakeisa.

Wijaya, A., et al. (2020). Barislam Jalan Tengah. Yogyakarta: IRCiSoD. 